\title{
A Review of the Organic Synthesis and Medicinal Applications of the Natural Product Cytisine
}

\author{
Dorota Bartusik ${ }^{1^{*}}$, David Aebisher ${ }^{2}$ and Piotr Tutka ${ }^{3,4}$ \\ ${ }^{1}$ Southern Polytechnic State University, Department of Biology and Chemistry, 1100 South Marietta Parkway, \\ Marietta, Georgia 30060, USA \\ ${ }^{2}$ Shorter University, Natural Sciences Department, 315 Shorter Ave, Rome, Georgia 30165, USA \\ ${ }^{3}$ University of Rzeszów, Department of Pharmacology, Al. Rejtana 16C, 35-959 Rzeszów, Poland \\ ${ }^{4}$ University of Rzeszów, Laboratory of Pharmacoepidemiology, Centre for Innovative Research for Medical and \\ Natural Sciences, Al. Rejtana 16C, 35-959, Rzeszów, Poland \\ Email: dorota.bartusik@gmail.com
}

\begin{abstract}
Cytisine (CYT) is a naturally occurring chiral alkaloid which is known to be a ligand of nicotinic acetylcholinergic receptors (nAChRs). This compound has been a subject of quite intensive pharmacological research to explore CYT impact on the nAChRs. CYT may be a both more clinically effective and more cost-effective smoking cessation aid than varenicline (the most effective, but most expensive smoking cessation medication currently available), which belongs to the same category of agonists. Several strategies have been developed for the synthesis of CYT and its derivatives. Herein we review the strategies that have been employed for the synthetic formation of the tricyclic CYT molecule. Synthetic approaches include the formation of ( \pm -CYT from bipyridines, synthesis of (+)-CYT using chiral pools and the use of microorganisms to synthesize (-)-CYT. Due to the clinical importance of CYT, we hope a review of synthetic pathways may advance research into CYT.
\end{abstract}

Keywords: Cytisine, nicotinic acetylcholinergic receptors, alkaloid

\section{Introduction to Cytisine Chemistry}

Cytisine (CYT), a naturally occurring quinolizidine alkaloid, is the oldest medication for smoking cessation [1-3] widely used in Central/Eastern Europe and Central Asia. The drug remained unnoticed as a smoking cessation medication to Western countries and the US and was not cited in the Englishlanguage literature until $2006[1,3]$. The clinical observations and large studies demonstrating the effectiveness of CYT coupled with the potential very low cost of therapy make CYT an attractive drug for smoking cessation which should become more widely available. According to the latest recommendations of world's experts, CYT should be licensed worldwide as soon as possible [4-9].

In 1862, Husemann and Marme isolated pure (-)-CYT from seeds of Laburnum anagyroides [10]. The chemical structure of CYT was determined using analyses developed by several researchers: Partheil, Freund, Ing and Spath [11-15]. The structure of CYT, a member of the lupin alkaloid family, was studied by chemists for more than eight decades. The correct molecular formula $\left(\mathrm{C}_{11} \mathrm{H}_{14} \mathrm{~N}_{2} \mathrm{O}\right)$ of $\mathrm{CYT}$ was described in 1890 by Partheil [16]. The absolute configuration of naturally occurring CYT was determined in 1944 by the synthesis of $(1 \mathrm{R}, 5 \mathrm{~S}, 12 \mathrm{~S})-\mathrm{N}$-tosyl tetrahydrodeoxocytisine from CYT [17]. This early work established the structure of CYT $[17,18]$ and its absolute configuration and was assigned as [(1R,5S)-1,2,3,4,5,6-hexahydro-1,5-methano-8H-pyrido[1,2][1,5]. The first synthetic sample of CYT was obtained by van Tamelen and Baren as a racemic mixture [19]. Studies on synthetic strategies for CYT construction have increased over the past twenty years since it is recognized as a partial agonist of nicotinic acetylcholinergic receptors (nAChRs) with a high affinity for the $\alpha 4 \beta 2$ subtype of nAChRs [20,21]. For many years CYT has been used by pharmacologists to examine the function of nAChRs. Very encouraging results of recent clinical trials and strong theoretical background for its use make CYT an affordable alternative for currently available antismoking treatments, particularly in underdeveloped countries where smoking rates are rising and smoking cessation treatments are too 
expensive $[4,8,22]$. Therefore, CYT has recently started to serve as a prototype and vehicle for the synthesis of new compounds as possible aids to smoking cessation.

The next syntheses of achiral $(( \pm)$-cytisine) CYT was reported by chemists at Pfizer in 2000 [23,24] and was closely followed by the work of Gallagher and coworkers in 2006 [25]. The first asymmetric synthesis of (-)-CYT was reported by Danieli in 2004 [26]. In the same year, Honda and coworkers synthetized (+)-CYT using a chiral pool approach [27]. To date, several reviews and monographs discussing the synthesis and properties of CYT have been published $[1,28,29]$. The structure and numbering of CYT is shown in Figure 1.
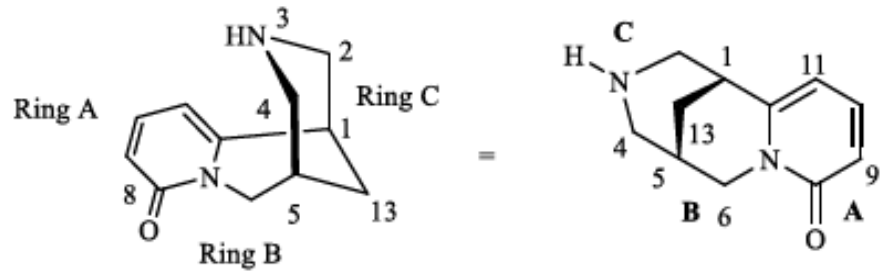

Figure 1. Structure and absolute configuration of (-)-CYT with IUPAC numbering of the atoms.

The CYT molecule has affinity for nAChRs subtypes composed of $\alpha_{4}$ and $\beta_{2}$ subunits $\left(\alpha_{4} \beta_{2}\right.$ nAChRs $)$ [20]. The $\alpha_{4} \beta_{2}$ nAChRs are known as fundamental receptors in physiology because they mediate various brain functions and represent an important target for drug discovery. Studies have shown that CYT prevents other ligands, such as nicotine, from binding to the $\alpha_{4} \beta_{2} n A C h R s$ due to its greater affinity [30]. A growing body of evidence strongly implicates the involvement of $\alpha_{4} \beta_{2} n A C h R s$ in the addictive effects of nicotine [31,32]. The nAChRs play a key role in the dopamine-releasing effects of nicotine [33]. An increase in the dopamine level is responsible for pharmacological reward whereas lower dopamine levels are associated with the withdrawal symptoms experienced by smokers during cessation attempts. Therefore, CYT derivatives have attracted much interest as a target for smoking cessation therapies [34,35]. Moreover, (-)-CYT derivatives have also been evaluated as potential drugs for the treatment of Alzheimer's and Parkinson's disease [36,37].

CYT exhibits poor brain penetration which, to some extent, limits its clinical usefulness. The reason for the low brain exposure of CYT is unclear. As the lipophilic characteristics of a drug are most frequently used to indicate the probable penetration of the drug through the blood-brain barrier, the limited brain penetration of CYT has been attributed to its high lipophilicity that has a lower logP value than nicotine $[1,38]$. On the other hand, there are speculations that the low brain concentrations of CYT could be due to active, non-P-gp, non BCRP efflux mechanism [39], however, no study supporting this speculation has been performed. In the past years trials of drug modification to improve the penetration of the blood-brain barrier have been performed [40].
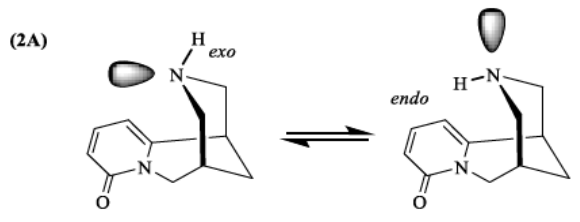

(2B)

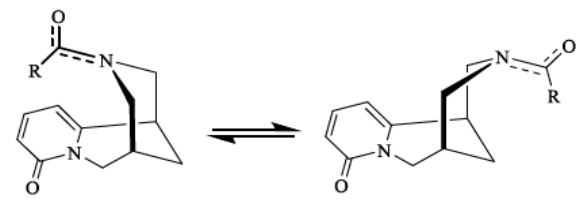

cis trans

Figure 2. (2A) Anomeric equilibria and (2B) conformations of (-)-N-acetylcytisines in DMSO solutions. 
A weak CYT absorption through the blood brain barrier may be caused by nitrogen protonation at physiological $\mathrm{pH}$. The presence of reactive free electron pairs on the secondary nitrogen atom also permits a number of derivatives to be constructed [40-43] whose biological activity may be greater than that of CYT itself. Figure 2A shows an anomeric equilibrium between two stable conformers when the hydrogen of the piperidine nitrogen is in the exo or endo orientation. In the liquid state, the conformation of the hydrogen atom on the piperidine nitrogen is inverted in the range of $10^{4}-10^{5} \mathrm{~s}^{-1} \mathrm{due}$ to minimization of steric effects between ring B and C. Figure 2B shows that a solution of (-)-Nacylcytisine in DMSO is in cis-trans equilibrium with ring $\mathrm{C}$ in chair and boat conformations, respectively.

In the solid state, the exo conformer forms intermolecular hydrogen bonds $(\mathrm{C}=\mathrm{O} \cdots \mathrm{H}-\mathrm{N})$. Figure 3 shows stabilization in the solid phase by hydrogen bonding between the equatorial hydrogen of the piperidine nitrogen with the piperidone oxygen of a second molecule [44].

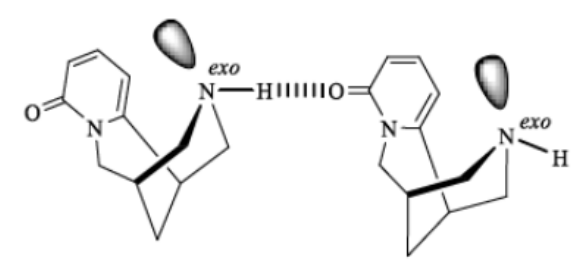

Figure 3. Conformations of (-)-CYT in the solid phase.

\section{$2 \quad$ Material and Methods}

The research discussed here reflects the synthesis techniques of cytisine. The data was collected from the PubMed database. The key steps of the cytisine syntheses are presented in the paragraphs below.

\section{Cytisine Syntheses}

The general strategies for the CYT syntheses are presented below based upon final ring closure of the tricyclic structure (A, B or C) in Figure 4.

Among the total synthesis of CYT reported are syntheses using pyridine-derived A ring $[19,24,27]$, glutarimide or pyridone-derived A ring [23,25], pyridine derived B-ring [45,46], piperidine derived C-ring [26] and constructions of bispidine core by O'Brien and coworkers $[47,48]$. The synthetic routes to obtain Ring A were fully developed by O'Brien and coworkers. Their research presents a synthesis of $( \pm)$-CYT using a ring closing metathesis (RCM) to form ring A (4a) [47]. In syntheses by Bohlmann [49] and Govindachari [46], ring $\mathrm{C}$ was built from conveniently substituted quinoline-4-one derivatives (4b). Both of the syntheses employed a trisubstituted starting pyridine to build CYT. The formation of the $\mathrm{C}_{6}-\mathrm{N}_{7}$ bond of ring $\mathrm{B}(4 \mathrm{c})$ is the most common route to $( \pm)$-CYT. The bond $\mathrm{C}_{6}-\mathrm{N}_{7}$ results from nucleophilic substitution of a leaving group by the nitrogen of pyridine or of a dihydropyridinone [19]. The $\mathrm{C}_{1}-\mathrm{C}_{12}$ bond (4d) is linked via an intermolecular 1,6-nucleophilic addition of piperidinone or piperidone enolate [25] to a pyridone ring mediated by base or via a palladium mediated Hartwig's $\alpha$-arylation of a bromopyridone. The most recent attempts have been to prepare enantiopure CYT.

All of the known total syntheses of CYT are described in detail below. The best yield in range 16-35\% is obtained by Coe's five step synthesis of $( \pm)$-CYT. Despite these approaches described below which represent the best known routes of CYT synthesis, there is still need to develop new synthetic strategies with higher yield, shorter synthetic steps, and more efficient asymmetric routes. 


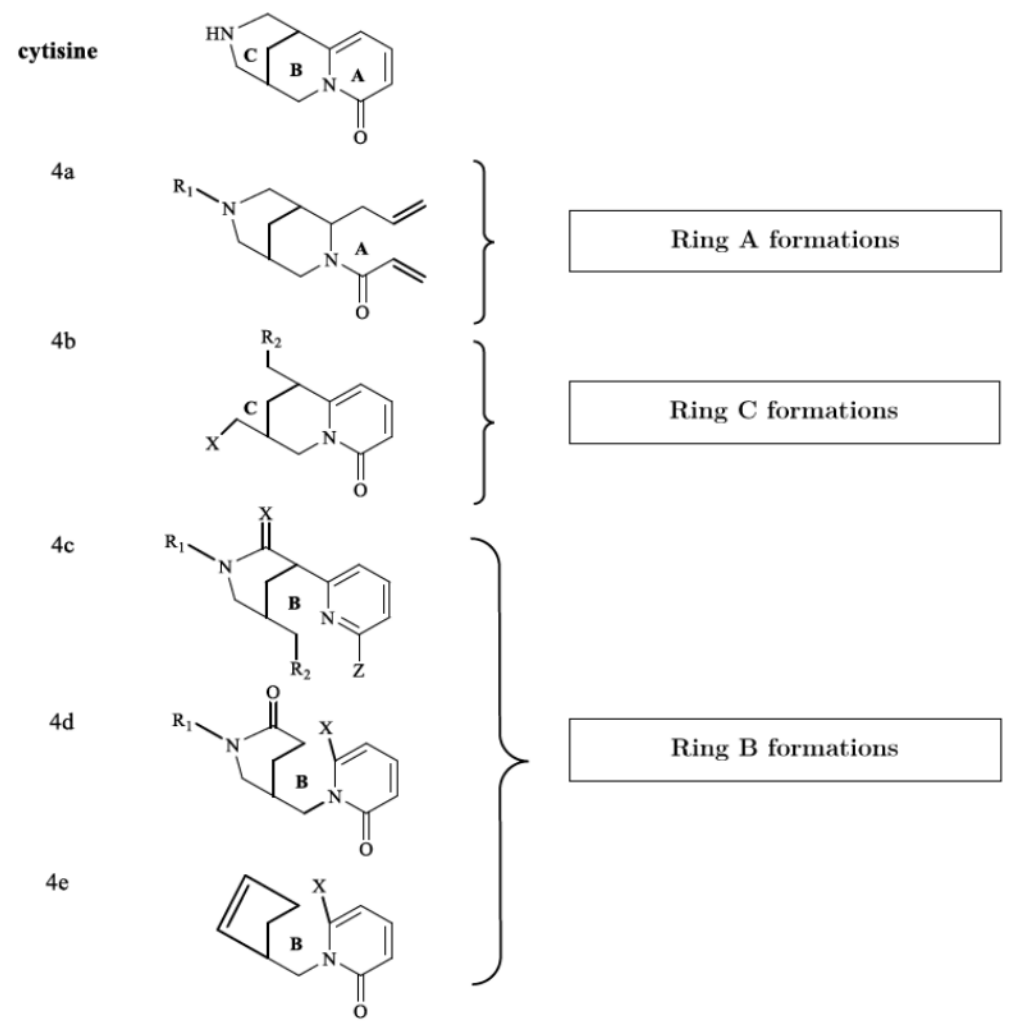

Figure 4. Formations of cytisine rings A, B and C. Abbreviations are: (4a) $R_{1}=$ protecting group; (4b) $R_{2}=$ leaving group and $\mathrm{X}=\mathrm{R}_{2}$ or $\mathrm{NH}_{2} ;(4 \mathrm{c}) \mathrm{R}_{1}=$ protecting group, $\mathrm{X}=\mathrm{CH}_{2}$ or $\mathrm{O}, \mathrm{Z}=\mathrm{H}$, or $\mathrm{OMe}$; (4d) $\mathrm{R}_{1}=$ protecting group, $\mathrm{X}=\mathrm{R}_{2}$, (4d) $\mathrm{X}=\mathrm{R}_{2}$.

\subsection{Bohlmann's Synthesis of $( \pm)$-Cytisine}

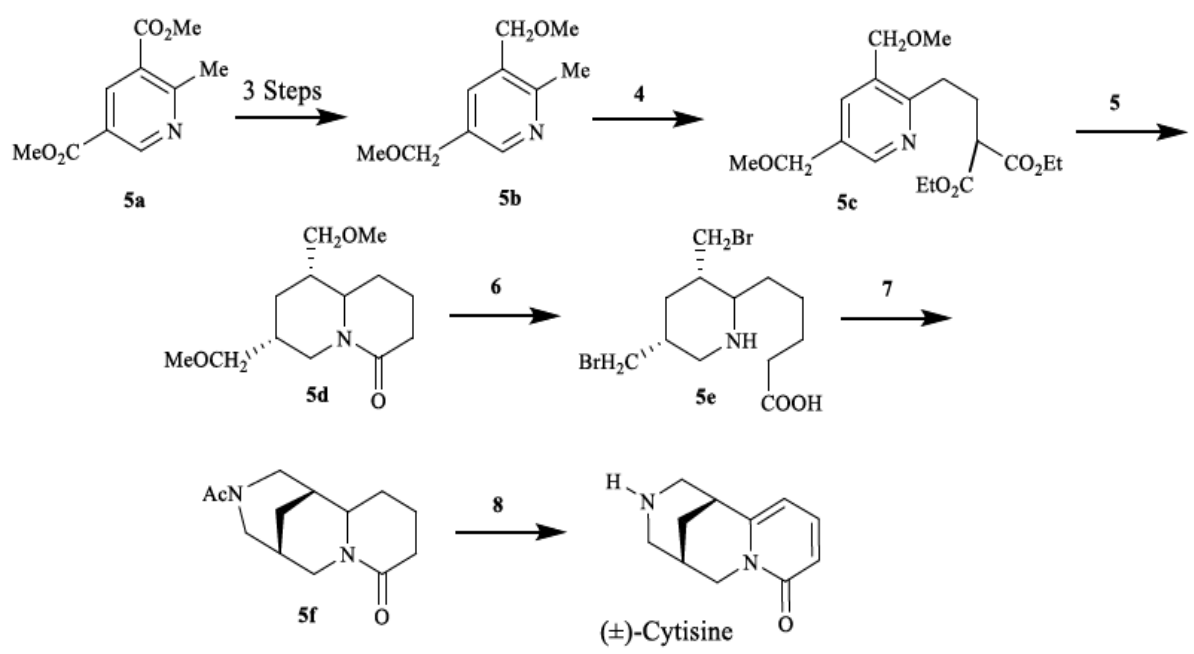

Figure 5. Bohlmann's synthesis ${ }^{1}$.

1 (4) (i) $\mathrm{HCHO}$ at $140^{\circ} \mathrm{C}$, (ii) $\mathrm{H}_{2} \mathrm{C}\left(\mathrm{CO}_{2} \mathrm{Et}\right)_{2}$, NaOEt, reflux; (5) (i) Raney Ni, dioxane (ii) $\mathrm{H}_{2}\left(200 \mathrm{bar}\right.$ ), $185^{\circ} \mathrm{C}$, 2h; (6) (i) $\mathrm{HBr}$ at $120^{\circ} \mathrm{C}$, (ii) $\mathrm{NH}_{3}$, EtOH, $0^{\circ} \mathrm{C}$, (iii) methylnaphthalene, $200^{\circ} \mathrm{C}$, $\mathrm{MeOH}$; (7) $\mathrm{Ac}_{2} \mathrm{O}$ at $100^{\circ} \mathrm{C}$; (8) (i) $\mathrm{Pd} / \mathrm{C}$ and (ii) $\mathrm{HCl}$. 
Figure 5 presents the total synthesis of $( \pm)$-CYT conducted by Bohlmann and coworkers [49]. The synthesis of $( \pm)$-CYT described here utilizes 7,9-di(methoxymethyl)-4-quinolizidine as an intermediate $(5 \mathrm{~d})$. In order to prepare this compound, diethyl-2-methyl-3,5-pyridinedicarboxylate (5a) was reduced with lithium aluminum hydride to the glycol which was transformed to the diether 3,5(dimethoxymethyl)-2-methylpyridine (5b). This compound was converted to 3,5-(dimethoxymethyl)-2vinylpyridine and Michael addition of malonic ester was followed by reductive cyclization to produce (5d). Rings A and B were constructed from diethyl-2-methyl-3,5-pyridinedicarboxylate and ethoxymethylenemalonic ester to form 3,5-pyridinecarboxyate and the peroxide of glutaric acid half ester (5c). Compound (5d) was cleaved with hydrogen bromide to the di(bromomethyl)intermediate (5e) which was converted by heating in ethanolic ammonia in an autoclave followed by heating in methylnaphthalene to $5 \mathrm{f}$. By applying a dehydrogenation on $\mathrm{Pd} / \mathrm{C}$, $5 \mathrm{f}$ was converted to $( \pm)$-CYT.

\subsection{Coe's Synthesis of $( \pm)-C Y T$}

Coe's synthesis of $( \pm)$-CYT [21] starts with N-alkylation of glutarimide via deprotonation and reaction with mesylate $(\mathbf{6 b})$ in the presence of $\mathrm{nBu}_{4} \mathrm{~N}^{+} \mathrm{I}^{-}$and $\mathrm{DMF}$ to give an imide.

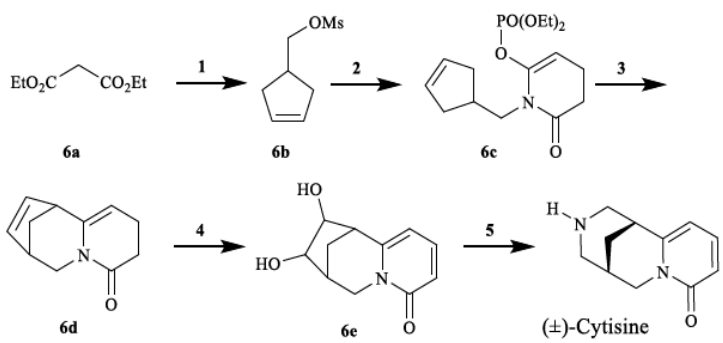

Figure 6. Coe's Synthesis2.

Deprotonation of the imide using lithium bis(trimethylsilyl)amide (LHMDS) and subsequent reaction with diethyl chlorophosphate furnished enol phosphate $(\mathbf{6 c})$ in quantitative yield. The key intramolecular Heck reaction of enol phosphate (6c) was accomplished to give tricyclic lactam $(\mathbf{6 d})$. The dihydroxylation of the cyclopentene unit afforded diol $(\mathbf{6 e})$. The diol was then transformed into $( \pm)$ CYT.

\subsection{Van Tamelen's Synthesis}

Van Tamelen and Baren used a monosubstituted pyridine (7a) derivative as a starting compound of the A-ring of CYT (Figure 7) [19].

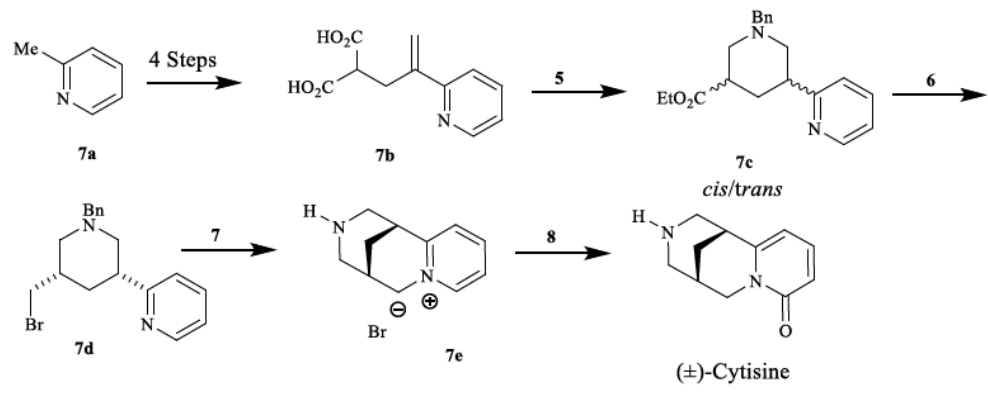

Figure 7. Van Tamelen's synthesis ${ }^{3}$.

2 (1) (i) glutarimide, t-BuOK, C, THF, (ii) mesylate, cat. DMF, cat. $\mathrm{nBu}_{4} \mathrm{NI}$, (2) (i) LHMDS, THF, 78 to $23^{\circ} \mathrm{C}$; (ii) $\mathrm{ClP}(\mathrm{O})(\mathrm{OEt})_{2}$ (3) 1.5 equiv $\mathrm{Et}_{3} \mathrm{~N}, 2.0 \mathrm{~mol} \% \mathrm{Pd}(\mathrm{OAc})_{2}, 4 \mathrm{~mol} \% \quad \mathrm{P}(\mathrm{o}-\mathrm{tol})_{3}, \mathrm{MeCN}, 60^{\circ} \mathrm{C}$ (4) (i) 10-20 equiv $\mathrm{MnO}_{2}$, benzene, (ii) $\mathrm{Me}_{3} \mathrm{NO} \cdot 2 \mathrm{H}_{2} \mathrm{O}$, cat. $\mathrm{OsO}_{4}, \mathrm{CH}_{2} \mathrm{Cl}_{2}$; (5) (i) 1 equiv. $\mathrm{NaIO}_{4}, \mathrm{EtOH} / \mathrm{H}_{2} \mathrm{O}$ (ii) $\mathrm{NH}_{4} \mathrm{OH}, \mathrm{H}_{2}, \mathrm{Pd}(\mathrm{OH})_{2}$.

3 (5) $\mathrm{HCl}, \mathrm{BnNH}_{2}, \mathrm{HCHO},(6) \mathrm{Na}$, EtOH, $\mathrm{LiAlH}_{4}, \mathrm{HBr}(7): \mathrm{C}_{6} \mathrm{H}_{6}$, reflux; (8) $\mathrm{K}_{3} \mathrm{Fe}(\mathrm{CN})_{6}, 100^{\circ} \mathrm{C}$ followed by $\mathrm{AuCl}_{3}$ at $150^{\circ} \mathrm{C}$. 
Compound (7b) was formed in 4 steps from monosubstituted pyridine (7a) and was followed by a tandem Mannich addition-decarboxylation which enabled formation of ring $\mathrm{C}$ (7c). Compound (7c) represents a mixture of cis and trans isomers. Epimerization of the trans to the cis isomer was carried out to improve the yield of the ring-closure step. Functional transformation of the cis ester to bromide (7d) allowed ring B formation via intramolecular nucleophilic substitution (7e). Oxidation and deprotection of the secondary amine afforded ( \pm -CYT.

\subsection{O’Neill Synthesis of ( \pm -Cytisine}

Figure 8 presents O'Neill's total synthesis of ( \pm -CYT [24]. Bis-pyridine (8b) was synthetized using bromopyridines $(8 \mathrm{a} 1+8 \mathrm{a} 2)$ and optimized palladium(0)-coupling protocol. The selective reduction of one of the pyridine rings in 3,5-disubstituted pyridines such as (8b) is linked to the oxidation level of the substituents.

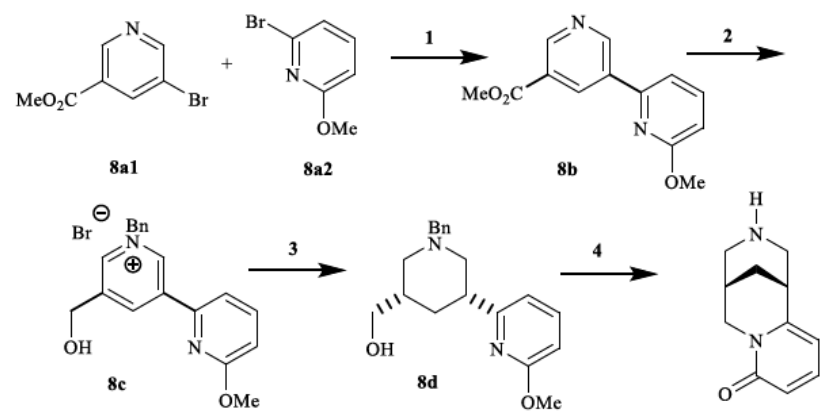

( \pm )-Cytisine

Figure 8. Van Tamelen's synthesis ${ }^{4}$.

It was found that the ester in (8b) had to be reduced to a primary alcohol prior to benzylation. After reduction, chemoselective benzylation of the least sterically hindered pyridine nitrogen gave the pyridinium salt (8c), providing the required activation for selective hydrogenation using $\mathrm{H}_{2}$ and $\mathrm{PtO}_{2}$. In this way, a quantitative yield of an 85:15 mixture of piperidines cis- and trans- (8d) was obtained. Mesylation of $8 \mathrm{~d}$ followed by heating in toluene yielded N-benzylcytisine which was debenzylated to form ( \pm -CYT. O'Neil and coworkers contributed significantly to review of the (-)-CYT synthesis [50].

\subsection{Gallagher's Synthesis of $( \pm)$-Cytisine}

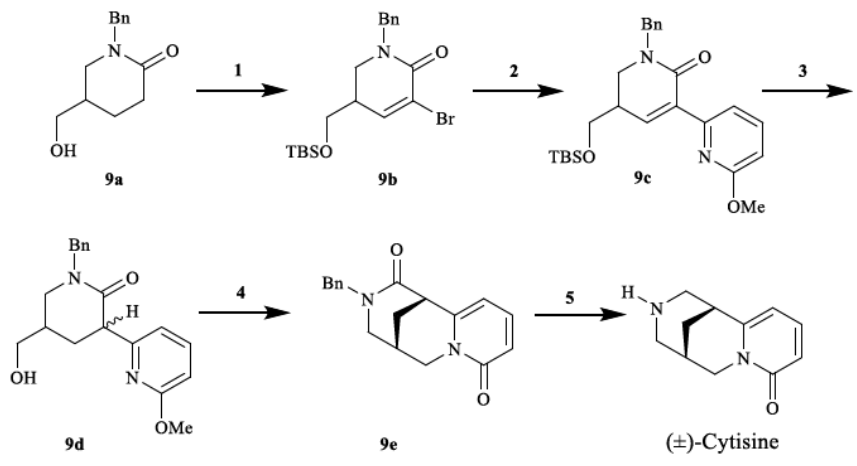

Figure 9. Gallagher's synthesis of $( \pm)-\mathrm{CYT}^{5}$.

4 (1) (i) n-BuLi, Et2O, -40 ${ }^{\circ} \mathrm{C}$; (ii) $\mathrm{B}(\mathrm{OMe}) 3$; (iii) cat. $\mathrm{Pd}(\mathrm{PPh} 3) 4,2$ equiv CsF, DME, 85ํㅡ, 12 h; (2) LiAlH4, Et2O; (c) BnBr, MeCN; (3) H2, $\mathrm{PtO} 2, \mathrm{Et} 3 \mathrm{~N} / \mathrm{MeOH}$; (4) (i) MsCl, Et3N, CH2Cl2; (ii) toluene, reflux (iii) H2, $\mathrm{Pd}(\mathrm{OH}) 2, \mathrm{NH} 4+\mathrm{HCOO}-, \mathrm{MeOH}$.

5 (1) (i) $\mathrm{TBSCl}, \mathrm{Et}_{3} \mathrm{~N}$, (ii) $\mathrm{BuLi}, \mathrm{PhSeCl}$ then $\mathrm{NaIO}_{4}$, (iii) $\mathrm{Br}_{2}$ then $\mathrm{Et}_{3} \mathrm{~N}$; (2) (i) $\mathrm{Pd}\left(\mathrm{PPh}_{3}\right)_{4}, \mathrm{CuCl}, \mathrm{LiCl}$; (3) (i) $\mathrm{H}_{2}, \mathrm{Pd} / \mathrm{C},($ ii) TBAF; (4) (i) $\mathrm{MsCl}, \mathrm{Et}_{3} \mathrm{~N}$, PhMe/DMF (ii) LHMDS; (5) (i) $\mathrm{BH}_{3}-\mathrm{THF}$, (ii) $\mathrm{H}_{2}, \mathrm{Pd}(\mathrm{OAc})_{2}$ 
Gallagher's synthesis of $( \pm)$-CYT is summarized in Figure 9 [51]. Unsaturated lactam (9a) was used to obtain bromide (9b) in step 1. The amide precursor (9c) was constructed by the union of (9b) with bromopiridone via N-pyridone N-alkylation. Hydrogenation of dihydropyridone (9c) followed by desilylation afforded a mixture of cis and trans lactams (9d). Mesylation of the diastereoisomeric mixture (9d), then thermal cyclization led to lactam (9e). In this case, $( \pm)$-cytisine is derived from lactam $(9 \mathrm{e})$ by amide reduction. Lactam (9e) was obtained by mesylation of diastereoisomeric mixture (9d) and then thermal cyclization.

\subsection{Govindachari's Synthesis}

The trisubstituted pyridine (10a) was formed allowing for conversion into the bis-ester (10b) via reaction of (10a) with Michael acceptor and KOEt in EtOH [46]. This reaction presumably proceeds by methyl group deprotonation, Michael addition and ethoxide elimination to give an intermediate in which the pyridine nitrogen cyclizes onto one of the esters to ultimately form quinolizinone (10b). Chemoselective reduction of the nitrile to a primary amine gave an aminoquinolizinone, in which one of the ester groups was removed by hydrolysis $(6 \mathrm{M} \mathrm{HCl}(\mathrm{aq}))$ and decarboxylation upon heating. The crude amino acid was then re-esterified using $\mathrm{HCl}$ in $\mathrm{EtOH}$ to give the amino ester (10c). $\mathrm{LiAlH}_{4}$ reduction was used to convert the ester into a primary alcohol (10d). Chemoselective reduction of the pyridine ring in (10d) (leaving the pyridone ring intact) was accomplished using hydrogen $/ \mathrm{PtO}_{2}$ to give cis-10e. Then, crude cis-10e was treated with $\mathrm{PBr}_{3}$ to transform the hydroxyl group into a bromide and cyclisation was carried out by heating at $100^{\circ} \mathrm{C}$ with $\mathrm{K}_{2} \mathrm{CO}_{3}$ in a sealed tube to give a $4 \%$ yield of $( \pm)$ CYT.

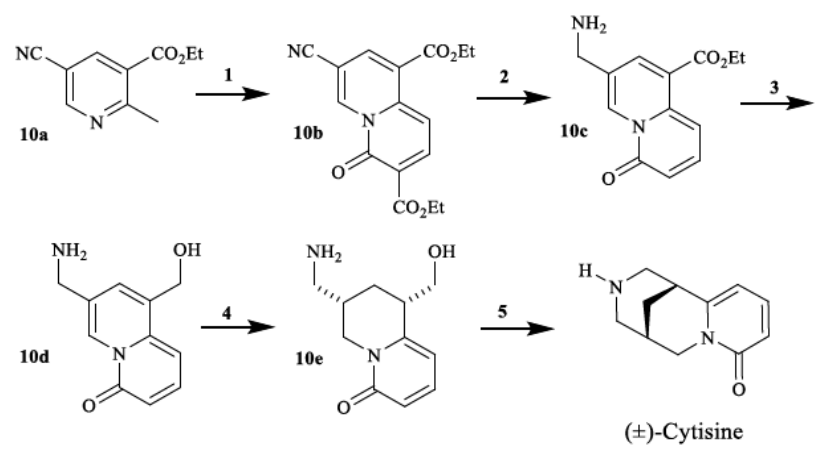

Figure 10. Govindachari's Synthesis ${ }^{6}$.

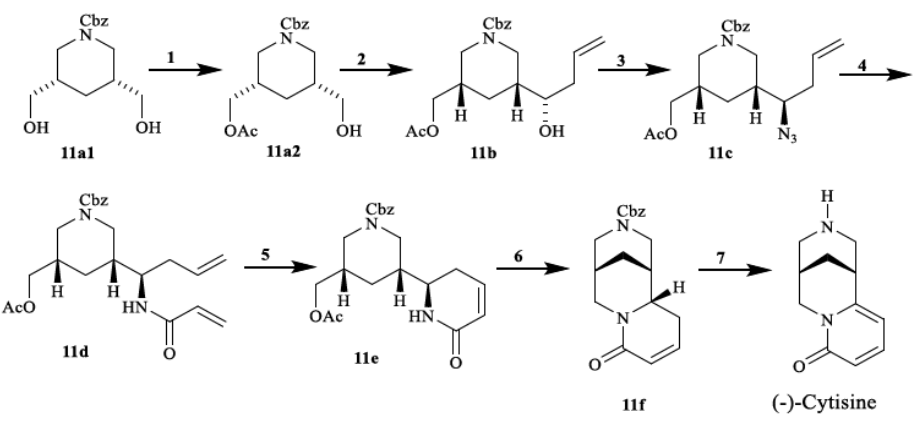

Figure 11. Lesma's Synthesis ${ }^{7}$.

6 (1) diethyl ethoxymethylenemalonate 60, KOEt/EtOH, reflux, 4 h; (2) (i) $\mathrm{PtO}_{2}, \mathrm{H}_{2}$, EtOH; (ii) 6M HCl(aq), reflux, 1 h; (iii) $\mathrm{HCl}$, EtOH; (3) $\mathrm{LiAlH}_{4}, \mathrm{Et}_{2} \mathrm{O}$; (4) $\mathrm{PtO}_{2}, \mathrm{H}_{2}$; (5) (i) $\mathrm{PBr}_{3}$, benzene, $100^{\circ} \mathrm{C}, 4 \mathrm{~h}$; (ii) $\mathrm{K}_{2} \mathrm{CO}_{3}, 18 \mathrm{~h}$, sealed tube, $100^{\circ} \mathrm{C}$.

7 (1) Pseudomonas fluorescens lipase $(\mathrm{PFL})$, vinyl acetate $(2)(\mathrm{COCl})_{2}, \mathrm{DMSO}_{2} \mathrm{Et}_{3} \mathrm{~N}, \mathrm{CH}_{2} \mathrm{Cl}_{2}$; (3) allyldiisopinocampheylborane,

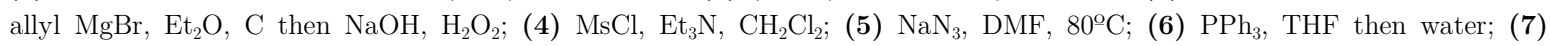
acryloyl chloride, $\mathrm{Et}_{3} \mathrm{~N}, \mathrm{CH}_{2} \mathrm{Cl}_{2} ;$ (8) $\mathrm{Ru}(\mathrm{CHPh})\left(\mathrm{PCy}_{3}\right)_{2} \mathrm{Cl}_{2}, \mathrm{CH}_{2} \mathrm{Cl}_{2}$, reflux; (9) $\mathrm{NaOH}, \mathrm{THF} ;(\mathbf{1 0}) \mathrm{MsCl} \mathrm{Et}_{3} \mathrm{~N}, \mathrm{CH}_{2} \mathrm{Cl}_{2} ;(\mathbf{1 1})$ $\mathrm{NaH}$, THF,rt; (12) DDQ, 1,4-dioxane, reflux; (13) $6 \mathrm{M}, \mathrm{HCl}$, reflux. 


\subsection{Lesma's Synthesis}

Cis diol (11a) was the starting compound for the synthesis of (-)-CYT [26].

Enzymatic acetylation of the diol (11a) using Pseudomonas fluorescens lipase yields monoacetate (11b). Compound (11c) was formed by using allyldiisopinocampheylborane. The amine (11d) was generated by mesylation of alcohol and by reaction with $\mathrm{NaN}_{3}$ in DMF. In the next step, 11d was reacted with Grubbs' first-generation catalyst to achieve ring-closing metathesis to (11e). The pyridone 11f was constructed from diene (11e) via a ring closing metastasis. Dihydropirydone (11g) was formed from cis-piperidine. (-)-CYT was obtained by oxidation, N-deprotection of $11 f$.

\subsection{Synthesis via Initial Construction of the Bispidine Core (BC-Rings)}

The synthesis of (-)-CYT was obtained by the double-Mannich reaction of N-Boc piperidone (12a) with benzylamine and paraformaldehyde, which resulted in bispidinone (Figure 12). The carbonyl group was removed via the formation of the tosyl hydrazone and reduction with $\mathrm{NaBH}_{4}$ to give (12b). Construction of the pyridine ring started with allylation of (12b). Thus, deprotonation of bispidine (12b) at the position $\alpha$ to the N-Boc group was obtained by the use of s-BuLi/TMEDA in $\mathrm{Et}_{2} \mathrm{O}$. Allylated N-Boc bispidine (12c) was produced as a single diastereomer, which is believed to arise by preferential equatorial lithiation and retention of configuration through subsequent processes (transmetalation and electrophilic trapping).

Next, allylated N-Boc bispidine (12c) was converted into diene (12d) by TFA deprotection and acylation with acryloyl chloride. Ring-closing metathesis was then used to form the dihydropyridone ring. Reaction of diene (12d) with Grubbs' first-generation catalyst in toluene at reflux generated dihydropyridone (12e). This ring-closing metathesis of $( \pm)$-CYT was completed in six steps. Oxidation and deprotection was necessary after ring-closing metathesis.

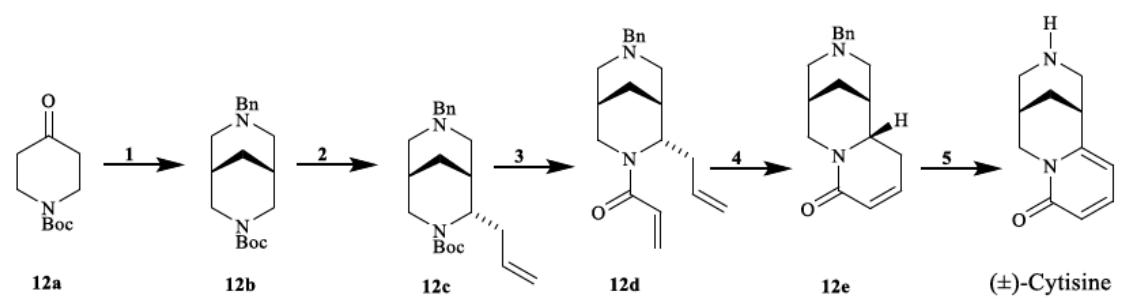

Figure 12. Synthesis via initial construction of the bispidine core (BC-rings) ${ }^{8}$.

\subsection{Honda's Synthesis}

Hydroxyproline derivative 13a was a starting compound for the (+)-CYT synthesis (Figure 13) [27]. Oxidation of 13a resulted in ketone 13b. Compound 13b was deprotonated and formed enol triflate 13c by reaction by O-triflylation using N-(5-chloro-2-pyridyl)triflimide. Stille coupling between enol triflate 13c and 2-tributylstannyl-6-methoxypyridine was used to install the 2-ethoxypyridine moiety 13d. Compound 13e was generated after Boc-deprotection of 13d and reductive deamination followed by lactam formation and benzylation. In the next step, using LDA and electrophilic trapping with ethyl chloroformate, a mixture of esters cis- and trans- $13 \mathrm{f}$ was obtained. The last two steps of the synthesis were completed to give (+)-CYT.

8 (1) (i) $\mathrm{BnNH}_{2}, \mathrm{AcOH},(\mathrm{CHO}) \mathrm{n}, \mathrm{MeOH}$, reflux, 5 h; (ii) TsNHNH 2 , EtOH, reflux, 2 h; (iii) $\mathrm{NaBH}_{4}, 4: 1 \mathrm{THF} /$ water, rt, $16 \mathrm{~h}$ then reflux, $3 \mathrm{~h}$; (2) (i) 1.6 equiv s-BuLi/TMEDA, $\mathrm{Et}_{2} \mathrm{O}, 7 \mathrm{~h}$; (ii) 1.0 equiv $\mathrm{CuCN} \cdot 2 \mathrm{LiCl}$, THF; (iii) 2.2 equiv allyldiphenyl phosphate; (3) (i) 1:1 TFA/ $\mathrm{CH}_{2} \mathrm{Cl}_{2}, 2 \mathrm{~h}$; (ii) $10 \% \mathrm{NaOH}(\mathrm{aq}), \mathrm{CH}_{2} \mathrm{Cl}_{2}$; (4) $\mathrm{Ru}(\mathrm{CHPh})\left(\mathrm{PCy}_{3}\right)_{2} \mathrm{Cl}_{2}$, toluene, reflux, $15 \mathrm{~min}$; (5) $10 \% \mathrm{Pd} / \mathrm{C}$, toluene/cyclohexene. 


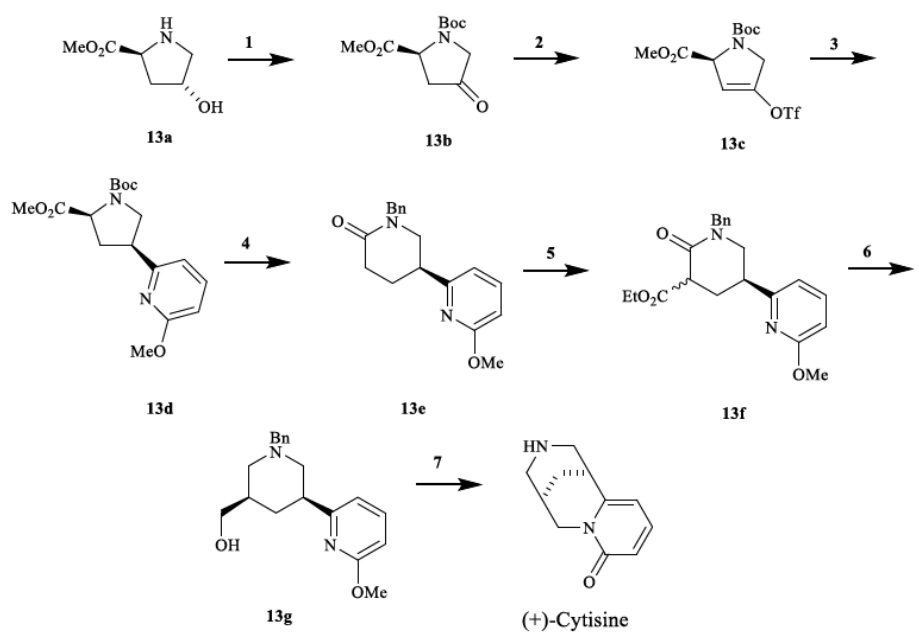

Figure 13. Honda's Synthesis ${ }^{9}$.

\section{Nicotinic Acetylcholine Receptors (Nachrs) and Its Ligand Cytisine}

A literature search revealed more than 2000 references reporting the synthesis of CYT and targeting of nAChRs. Over 300 research studies were published describing the synthesis of radio-labeled CYT. The variability and multiple combinations of $\mathrm{nAChRs}$ subunits and the lack of selective inhibitory ligands make studies of CYT very important. The binding characteristics of (-)-CYT have been intensively studied since 1980. It has been found that introduction of substituents modifying the molecular structure of CYT also changes its pharmacological properties, that is the affinity and inner activity towards certain nAChRs subtypes and the affinity to ganglionic and centric receptors $[43,52,53]$. Moreover, among N-substituted CYT derivatives, some compounds with analgesic activities have been found [54].

Additionally, it has been observed that the substituents on the ring at the N-3 position increase the affinity to the receptors $\alpha_{4} \beta_{2}$ while the C-5 substituents decrease the binding affinity [55].

Based on Figure 1, ring A of CYT and its derivatives assume a planar conformation, while ring B is in a chair conformation with the bridging C-8 atom directed out-of-plane. Ring $\mathrm{C}$ assumes a chair conformation and the nitrogen atom has a free electron pair in the axial position. The crystallographic data obtained for the CYT derivatives have confirmed the trans configuration with respect to the free electron pair on the nitrogen atom [56]. The same positions of the substituents are also indicated by the NMR spectra in solution.

(-)-CYT substituted with ${ }^{3} \mathrm{H}$ in the positions of 9- and 11- is called [ $\left.{ }^{3} \mathrm{H}\right]-\mathrm{CYT}$ and is often applied to study of binding to nAChRs. $\left[{ }^{3} \mathrm{H}\right]$-CYT has been extensively studied since $\left.1980 .{ }^{3} \mathrm{H}\right]$-cytisine is a crucial ligand for quantitation of neuronal nAChRs. The introduction of radionuclei in the CYT structure provides the opportunity for the use of positron emitting technology (PET) in targeting studies. It was demonstrated that at concentrations of $15 \mathrm{nM}\left[{ }^{3} \mathrm{H}\right]-\mathrm{CYT}$, the specific binding was $60-90 \%[20,57,58]$. The density of $\left[{ }^{3} \mathrm{H}\right]-\mathrm{CYT}$ binding sites in rat cortex was found to be close to unity with the binding of $\left[{ }^{3} \mathrm{H}\right]$-methylcarbamylcholine and $\left[{ }^{3} \mathrm{H}\right]$-nicotine $[20]$.

Carbon-substituted and N-substituted derivatives are potentially useful in the discovery of novel pharmacologically active compounds. Nitrated and halogenated derivatives of CYT were reported before

9 (1) (i) $\mathrm{Boc}_{2} \mathrm{O}, \mathrm{Et}_{3} \mathrm{~N}, \mathrm{CH}_{2} \mathrm{Cl}_{2}, \mathrm{rt}$; (ii) $(\mathrm{COCl})_{2}$, DMSO, $\mathrm{Et}_{3} \mathrm{~N}, \mathrm{CH}_{2} \mathrm{Cl}_{2}, 40^{\circ} \mathrm{C}$ to rt; (2) LHMDS, N-(5-chloro- 2-pyridyl)triflimide, $\mathrm{THF}, 78^{\circ} \mathrm{C}$ to $20^{\circ} \mathrm{C}$; (3) (i) $\mathrm{Pd}\left(\mathrm{PPh}_{3}\right)_{4}, \mathrm{LiCl}, \mathrm{CuI}$, 2-tributylstannyl-6-methoxypyridine, THF, $65^{\circ} \mathrm{C}$; (ii) $\mathrm{H}_{2}, \mathrm{Pd} / \mathrm{C}, \mathrm{MeOH}, \mathrm{rt}$, $100 \%$; (4) (i) TFA, $\mathrm{CH}_{2} \mathrm{Cl}_{2}, 0^{\circ} \mathrm{C}$; (ii) $\mathrm{SmI}_{2}$, THF/HMPA, MeOH, $0^{\circ} \mathrm{C}$ to rt; (iii) NaH, BnBr, THF/HMPA, THF, $0^{\circ} \mathrm{C}$ to rt; (iv) $\mathrm{LDA}, \mathrm{ClCO}_{2} \mathrm{Et}, \mathrm{THF}, 78^{\circ} \mathrm{C}$; (5) $\mathrm{LiAlH}_{4}$, THF, $0^{\circ} \mathrm{C}$ to rt; (6) (i) $\mathrm{MsCl}, \mathrm{Et}_{3} \mathrm{~N}, \mathrm{CH}_{2} \mathrm{Cl}_{2}, 0^{\circ} \mathrm{C}$; (ii) toluene, reflux; (7) $\mathrm{Pd}(\mathrm{OH})_{2}, \mathrm{NH}_{4}{ }^{+} \mathrm{HCOO}^{-}, \mathrm{MeOH}$, reflux. 
the structure was elucidated. To date, the halogenation reaction is the key route of CYT derivative synthesis because it has provided compounds with increased lipophilicity and higher affinity to nAChRs.

N-Methylcytisine, N-Butenylcytisine and N-formyl cytisine derivatives have also been found in plants. It was observed that the introduction of a substituent on the amine nitrogen decreased affinity of compound when compared to CYT [43]. Synthesis of N-substituted derivatives have shown that nitroso-, amino-, and hydroxyl- N- derivative are less efficient than CYT alone [59]. The binding of N-substituted derivatives was studied using PET and showed that the introduction of substituent on N-3 always brought a decrease of affinity in respect of CYT [60-62].

(-)-CYT derivatives have been developed by substituting the 6-C [42], 10-C [63], 9-C [30] and 11-C [30] positions in order to evaluate their binding properties to nAChRs. The first product of CYT bromination was provided in 1857 [64]. More recently, the synthesis of 9-bromo, 11-bromo and 9,11dibromo was developed with the yield of $27 \%, 27 \%$ and $5 \%$, respectively [30]. 9,11-dichlorocytisine was obtained by chlorination with $\mathrm{PCl}_{5}$ [65]. 9-iodo and 11-iodocytisine was obtained in the reaction with iodine chloride [30]. Also 9-fluoro, 11-fluoro and 9,11-difluoro were recently synthetized [66]. It has been reported 9-bromo [67], 9-iodo [30], 9-vinyl [30] and 10-methyl [62] cytisine display higher affinities and selectivities than CYT. For example, 9-bromocytisine has a 10-fold higher affinity for $\alpha_{4} \beta_{2} n A C h R$ than (-)-CYT itself. Table 1 presents a summary of binding affinities of halocytisine derivatives in the human brain.

Table 1. Ligand binding affinities of halocytisine derivatives to $\alpha_{4} \beta_{2}$ nicotinic acetylcholine receptors.

\begin{tabular}{|c|c|c|}
\hline Compound & $\begin{array}{lrl}\text { The relative } & \text { binding } \\
\text { constant }(\mathrm{nM}) & \\
\end{array}$ & References \\
\hline $9,11(\mathrm{Br})_{2}$ cytisine & 420 & {$[52]$} \\
\hline 9-I cytisine & 0.7 & {$[52]$} \\
\hline 11-I cytisine & 10 & {$[52]$} \\
\hline
\end{tabular}

Bromination at C-11, C-9 and C-9,11 afforded affinities higher than (-)-CYT. The same trend was observed in the human brain for the iodination product at $\mathrm{C}-11$. The addition of halogen to the CYT structure favors the hydrogen bonding between the CYT and receptor leading to higher affinity and efficacy. Another study of CYT analogues revealed that phenyl ring replacements of the pyridone ring of CYT reduced the binding affinities and functional efficacies [23]. Substitution at $\mathrm{N}-3$ by $-\mathrm{CH}=\mathrm{CH}_{2}[63]$ $-\mathrm{NO}_{2}$ [43] or pyridinyl [68], at $\mathrm{C}-4$ by $-\mathrm{CH}_{3}[62]$ or at C-5 by - Br could lead to the same or improved $\alpha_{4} \beta_{2}$-nAChRs binding affinity [69]. Substitution by $-\mathrm{CO}_{2} \mathrm{CH}_{3}$ or $-\mathrm{COCH}_{2} \mathrm{CH}_{3}$ at the piperidine nitrogen, at N-3 position [43,59], or at C-12 position has shown reduced affinity [63].

It is worth stressing that CYT is a good starting point for studies searching for novel compounds of potential therapeutic interest. The chemical modifications of CYT would be expected to increase its lipophilicity, thus improving its ability to pass the blood-brain barrier, to reduce the affinity for ganglionic receptors, and to alter its selectivity for different subtypes of central nAChRs [1]. Of the cytisine derivatives synthesized, only a few have succeeded in clinical trials [70]; however, it is very likely that over the next decade novel nicotinic receptor partial agonists with improved binding affinity and efficacy, and minimal side effects, will be advanced to the clinic to provide novel medications for smoking cessation. Biological testing of many CYT's derivatives is currently under way. A literature search confirms increasing interest in synthetic routes to cytisine [71]. Recently, a review dedicated to the study of varenicline and cytisine for smoking cessation was published by Cahil and coworkers [72]. In 2016, the asymmetric synthesis of (+)- and (-)-CYT was achieved by interconversions of functional group followed by ring closing metathesis [73]. To obtain (+)- and (-)-CYT these studies employed diastereospecific conversion in thirteen steps using Matteson homologations and bromination [73].

\section{Conclusion}

This review has shown that CYT is molecule with a unique and synthetically challenging structure which can bind to the $\alpha_{4} \beta_{2}$ subunit of nAChRs. During the past century, in particular in the last two decades, enormous progress has been made in understanding the chemistry of CYT. New synthetic 
methods including formation of $( \pm),(+)$ and (-)-CYT isomers have been reported. New strategies for the asymmetric synthesis of CYT and the development of new convenient methods for the optical resolution of racemic CYT will undoubtedly be reported in future studies. Moreover, recent studies of CYT have employed X-ray, Positron Emission Tomograpy (PET) and Magnetic Resonance Imaging (MRI) analysis [74]. The progress made thus far in the synthesis of CYT and derivatives is very promising for continued applications to nicotinic receptor targeting.

\section{References}

1. P. Tutka, W. Zatoński, "Cytisine for the treatment of nicotine addiction: from molecule to therapeutic efficacy", Pharmacology Report, vol. 58, pp.777-798, 2006.

2. J.J. Prochaska, S. Das, N.L. Benowitz, "Cytisine, the world's oldest smoking cessation aid", BMJ, vol. 347, pp. 5198, 2013.

3. E. Beard, L. Shahab, D.M. Cummings, Susan Michie, Robert West, "New Pharmacological Agents to Aid Smoking Cessation and Tobacco Harm Reduction: What Has Been Investigated, and What Is in the Pipeline? " CNS Drugs. pp. 1-33, doi:10.1007/s40263-016-0362-3, 2016.

4. P. Tutka, "Nicotinic receptors partial agonists as novel compounds for the treatment of smoking cessation", Expert Opinion on Investigational Drugs, vol. 17, pp. 1473-1485, 2008.

5. P. Aveyard, R. West, "Cytisine and the failure to market and regulate for human health", Thorax, vol. 68, pp. 989, 2013.

6. P. Hajek, H. McRobbie, K. Myers, "Efficacy of cytisine in helping smokers quit: systemic review and metaanalysis", Thorax, vol. 68, pp.1037-1042, 2013.

7. J.A. Stapleton, "The case for licensing cytisine now for smoking cessation is overwhelming", BMJ, vol. 347, pp. 5736, 2013.

8. N. Walker, C. Howe, M. Glover, H. McRobbie, J. Barnes, V. Nosa, V. Parag, B. Bassett, C. Bullen, "Cytisine versus nicotine for smoking cessation", New England Journal of Medicine, vol. 371, pp. 2353-2362, 2014.

9. N. Walker, C. Bullen, J. Barnes, H. McRobbie, P. Tutka, M. Raw, J.F. Etter, K. Siddiqi, R.J. Courtney, J. M. Castaldelli-Maia, P. Selby, J. Sheridan, N.A. Rigotti, "Getting cytisine licensed for use world-wide: a call to action", Addiction. doi: 10.1111/add.13464, 2016.

10. A. Husemann, A. Marmé,. "Cytisine", Ed in. Ned Journal, vol. 7, pp. 1025, 1862.

11. A. Partheil, "Zur Frage der Identität von Cytisin und Ulexin", Archives of Pharmacy, vol. 232, pp. 486-488, 1894.

12. M. Freund, A. Friedmann, "Zur Kenntnis des Cytisins", Berichte der deutschen chemischen Gesellschaft, vol. 34 pp. 605-619, 1901.

13. H.R. Ing, "Cytisine part I", Journal of Chemical Society, pp. 2195-2203, 1931.

14. H.R. Ing, "Cytisine part II", Journal of Chemical Society, pp. 2778- 2780, 1932.

15. M. Späth, "4-hydroxy-6,8-dimethylquinoline". Montash, vol. 40, pp. 93, 1919.

16. A. Partheil, "Ueber das Cytisin", Berichte der deutschen chemischen Gesellschaft, vol. 23(2), pp. 3201-3203, 1890.

17. F. Galinovsky, E. Stern, "Über die katalytische Reduktion einiger Alkaloide der Sparteingruppe, die einen Lactam- oder $\alpha$-Pyridonring enthalten", Berichte der deutschen chemischen Gesellschaft, vol. 77, pp. 132-138, 1944.

18. N.J. Leonard. In The Alkaloids; R. H. F. Manske, H.L. Holmes, Eds.; Academic Press: New York, Vol. 3, pp 119-199, 1953.

19. E.E. Van Tamelen, J.S. Baren, "The synthesis of dl-cytisine", Journal of American Chemical Society, vol. 77, pp. 4944-4945, 1955.

20. D.J Anderson, S.P. Arneric, "Nicotinic receptor binding of $[3 \mathrm{H}]$ cytisine, $[3 \mathrm{H}]$ nicotine and [3H]methylcarbamylcholine in rat brain", European Journal of Pharmacology, vol. 253, pp. 261-267, 1994.

21. J.W. Coe, P.R. Brooks, M.G. Vetelino, M.C. Wirtz, E.P. Arnold, J. Huang, S.B. Sands, T.I. Davis, L.A. Lebel, C.B. Fox, A. Shrikhande, J.H. Heym, E. Schaeffer, H. Rollema, Y. Lu, R.S. Mansbach, L.K. Chambers, C.C. Rovetti, D.W. Schulz, F.D. Tingley, B.T. O'Neill, "Varenicline, an R4 $\beta 2$ nicotinic receptor partial agonist for smoking cessation", Journal of Medicinal Chemistry, vol. 48, pp. 3474-3477, 2005. 
22. R. West, W. Zatoński, M. Cedzyńska, D. Lewandowska, J. Pazik, P. Aveyard, J. Stapleton, "Placebo-controlled trial of cytisine for smoking cessation", New England Journal of Medicine, vol. 365, pp. 1193-1200, 2011.

23. J.W. Coe, "Total synthesis of $( \pm)$-cytisine via the intramolecular heck cyclization of activated N-alkyl glutarimides", Organic Letters vol. 2, pp. 4205-4208, 2000.

24. B.T. O'Neill, D. Yohannes, M.W. Bundesmann, E.P. Arnold, "Total synthesis of ( \pm )-cytisine", Organic Letters, vol. 2, pp. 4201, 2000.

25. D. Gray, T. Gallagher, "A flexible strategy for the synthesis of tri- and tetracyclic lupin alkaloids: synthesis of (+)-cytisine, (+/-)-anagyrine, and (+/-)-thermopsine", Angewandte Chemie International Edition, vol. 45, pp. 2419-2423, 2006.

26. B. Danieli, G. Lesma, D. Passarella, A. Sacchetti, A. Silvani, A. Virdis, "Total Enantioselective Synthesis of (-)Cytisine", Organic Letters, vol. 6, pp. 493-496, 2004.

27. T. Honda, R. Takahashi, H. Namiki, "Syntheses of (+)-Cytisine, (-)-Kuraramine, (-)-Isokuraramine, and (-)Jussiaeiine", Journal of Organic Chemistry, vol. 70, pp. 499-504, 2005.

28. E.G. Pérez, C. Méndez-Gálvez, B.K. Cassels, "Cytisine: a natural product lead for the development of drugs acting at nicotinic acetylcholine receptors", Natural Products Reports, vol. 29, pp. 555-567, 2012.

29. L.F. Yu, H.K. Zhang, B.J. Caldarone, J.B. Eaton, R.J. Lukas, A.P. Kozikowski, "Recent developments in novel antidepressants targeting $\alpha 4 \beta 2$-nicotinic acetylcholine receptors", Journal of Medicinal Chemistry, vol. 57, pp. 8204-8223, 2014

30. P. Imming, P. Klaperski, M.T. Stubbs, G. Seitz, D. Gündisch, Syntheses and evaluation of halogenated cytisine derivatives and of bioisosteric thiocytisine as potent and selective nAChR ligands", European Journal of Medicinal Chemistry, vol. 36, pp. 375-388, 2001.

31. M.R. Picciotto, M. Zoli, R. Rimondini, C. Léna, L.M. Marubio, E.M. Pich, K. Fuxe, J.P. Changeux, "Acetylcholine receptors containing the beta2 subunit are involved in the reinforcing properties of nicotine", Nature vol. 391, pp. 173-177, 1998.

32. N.L. Benowitz,"Clinical pharmacology of nicotine: implications for understanding, preventing, and treating tobacco addiction", Clinical Pharmacology Therapy, vol. 83, pp. 531-541, 2008.

33. T.S. Rao, L.D. Correa, P. Adams, E.M. Santori, A.I. Sacaan, "Pharmacological characterization of dopamine, norepinephrine and serotonin release in rat prefrontal cortex by neuronal nicotinic acetylcholine receptor agonists", Brain Research, vol. 990, pp. 203-208, 2003.

34. C. Cohen, O.E. Bergis, F. Galli, A.W. Lochead, S. Jegham, B. Biton, J. Leonardon, P. Avenet, F. Sgard, F. Besnard, D. Graham, A. Coste, A. Oblin, O. Curet, C. Voltz, A. Gardes, D. Caille, G. Perrault, P. George, P. Soubrie, B. Scatton. "SSR591813, a novel selective and partial alpha4beta2 nicotinic receptor agonist with potential as an aid to smoking cessation", Journal of Pharmacology and Experimental Therapeutics, vol. 306, pp. 407-420, 2003.

35. H. Rollema, A. Shrikhande, K.M. Ward, F.D. Tingley, J.W. Coe, B.T. O'Neill, E. Tseng, E.Q. Wang, R.J. Mather, R.S. Hurst, K.E. Williams, M. de Vries, T. Cremers, S. Bertrand, D. Bertrand, "Pre-clinical properties of the alpha4beta2 nicotinic acetylcholine receptor partial agonists varenicline, cytisine and dianicline translate to clinical efficacy for nicotine dependence", British Journal of Pharmacology, vol. 160, pp. 334-345, 2010.

36. I. Hanin, R. Cacabelos, A. Fisher, "Recent Progress in Alzheimer's and Parkinson's Diseases. London: Taylor and Francis, pp. 383. ISBN 1-84184-320-2, 2005.

37. T.C. Durazzoa, N. Mattssona, M.W. Weinera, Smoking and increased Alzheimer's disease risk: "A review of potential mechanisms", Alzheimer's \& Dementia, vol. 10(3), pp. S122-S145, 2014.

38. C. Reavill, B. Walther, I.P. Stolerman, B. Testa, "Behavioral and pharmacokinetic studies on nicotine, cytisine and lobeline", Neuropharmacology, vol. 29, pp. 619-624, 1990.39. H. Rollema, J.W. Coe, L.K. Chambers, R.S. Hurst, S.M. Stahl, K.E. Williams, "Rationale, pharmacology and clinical efficacy of partial agonists of alpha4beta2 nACh receptors for smoking cessation", Trends in Pharmacological Sciences, vol. 28, pp. 316-325, 2007.

40. C.C. Boido, F. Sparatore, "Synthesis and preliminary pharmacological evaluation of some cytisine derivatives", Il Farmaco vol. 54, pp. 438-451, 1999.

41. E. Marrière, J. Rouden, V. Tadino, M. -C. Lasne, "Synthesis of analogues of (-)-cytisine for in vivo studies of nicotinic receptors using positron emission tomography", Organic Letters, vol. 2, pp. 1121-1124, 2000. 
42. J. Rouden, A. Ragot, S. Gouault, D. Cahard, J.-C. Plaquevent, M.-C. Lasne, "Regio- and diastereoselective functionalization of (-)-cytisine: an unusual N-C acyl migration", Tetrahedron: Asymmetry vol. 13, pp. 12991305, 2002.

43. C.C. Boido, B. Tasso, V. Boido, F. Sparatore, "Cytisine derivatives as ligands for neuronal nicotine receptors and with various pharmacological activities", Farmaco, vol. 58, pp. 265-277, 2003.

44. A.A. Freer, D.J. Robins, G.N. Sheldrake, "Structures of (-)-cytisine and (-)-N-methylcytisine: tricyclic quinolizidine alkaloids", Acta Crystallographica, vol. 43, pp. 1119-1122, 1987.

45. F. Bohlmann, A. English, N. Ottawa, H. Sander, W. Weise. "Lupinenalkaloide, IV. Totalsynthese der Cytisins (Zur Synthese des Cytisins, III.), Berichte der deutschen chemischen Gesellschaft, vol. 89, pp. 792-799, 1956.

46. T.R. Govindachari, S. Rajadurai, M. Subramanian, B.S. Thyagarajan, "Syntheses of protoberberine alkaloids", Journal of Chemical Society, pp. 3839-3844, 1957.

47. D. Stead, P. O'Brien, A. Sanderson, "Concise synthesis of (+/-)-cytisine via lithiation of N-Boc-bispidine", Journal of Organic Letters, vol. 7, pp. 4459-4462, 2005

48. D. Stead, P. O'Brien, "Total synthesis of the lupin alkaloid cytisine: comparison of synthetic strategies and routes", Tetrahedron, vol. 63, 1885-1897, 2007.

49. F. Bohlmann, N. Ottawa, R. Keller, I. Nebel, J. Politt, Lupinen-Alkaloide, I. Aufbau des "Tetrahydrochinolizons und des "Bispidins" (Beiträge zur Synthese des Cytisins)", Justus Liebigs Annuals Chemistry, vol. 587, pp. 162-176, 1954.

50. J.W. Coe, H. Rollema, B.T. O'Neil, Case history: Chantix ${ }^{\mathrm{TM}}$ Champix ${ }^{\mathrm{TM}}$ (varenicline Tartrate), a nicotinic acetylcholine receptor partial agonist as a smoking cessation aid, Annual Reports in Medicinal Chemistry, vol. 44, pp. 71, 2009.

51. C. Hirschhäuser, C. A. Haseler, T. Gallagher, "Core Modification of Cytisine: A Modular Synthesis", Angewandte Chemie International Edition, vol. 50, pp. 5162-5165, 2011.

52. Y.E. Slater, L.M. Houlihan, P.D. Maskell, R. Exley, I. Bermúdez, R.J. Lukas, A.C. Valdivia, B.K. Cassels, "Halogenated cytisine derivatives as agonists at human neuronal nicotinic acetylcholine receptor subtypes", Neuropharmacology vol. 44, pp. 503-513, 2003

53. U.S. Makhmudov, K.K. Turgunov, B. Tashkhodzhaev, V.A. Saprykina, K.M. Shakhidoyatov, "Crystalsolvates of N-(3-ethylthio-1,2,4-thiadiazol-5-yl-aminocarbonylmethyl)cytisine, Chemistry of Natural Compounds, vol. 44, pp. 466-471, 2008.

54. T.S. Rao, L.D. Correa, R.T. Reid, G.K. Lloyd, "Evaluation of anti-nociceptive effects of neuronal nicotinic acetylcholine receptor (NAChRs) ligands in the rat tail-flick assay", Neuropharmacology, vol. 35, pp. 393-405, 1996.

55. Y.E. Later, L.M. Houlihan, P.D. Maskell, R. Exley, I. Bermúdez, R.J. Lukas, A.C. Valdivia, B.K. Cassels, "Halogenated cytisine derivatives as agonists at human neuronal nicotinic acetylcholine receptor subtypes", Neuropharmacology vol. 44, pp. 503-515, 2003.

56. J.W. Coe, H. Rollema, B.T. O’Neill, "Progress in Heterocyclic chemistry", Annual Reports Meicinal Chemistry, vol. 44, pp. 71, 2009.

57. J.W. Sloan, W.R. Martin, M. Bostwick, R. Hook, E. Wala, "The comparative binding characteristics of nicotinic ligands and their pharmacology", Pharmacology Biochemistry \& Behavior, vol. 30, pp. 255-267, 1988.

58. L.A. Pabreza, S. Dhawan, K.J. Kellar, "[3H] cytisine binding to nicotinic cholinergic receptors in brain", Molecular Pharmacology, vol. 39, pp. 9-12, 1991.

59. O. Nicolotti, C. Canu Boido, F. Sparatore, A. Carotti, "Cytisine derivatives as high affinity nAChR ligands: synthesis and comparative molecular field analysis", Farmaco vol. 57, pp. 469-478, 2002.

60. E. Carbonnelle, F. Sparatore, C. Canu Boido, C., Salvagno, B. Baldani-Guerra, G. Terstappen, R. Zwart, H. Vijverberg, F. Clementi, C. Gotti, "Nitrogen substitution modifies the activity of cytisine on neuronal nicotinic receptor subtypes", European Journal of Pharmacology, vol. 471, pp. 85-96, 2003.

61. B. Tasso, C. Canu Boido, E. Terranova, C. Gotti, L. Riganti, F. Clementi, R. Artali, G. Bombieri, F. Meneghetti, F. Sparatore, "Synthesis, binding, and modeling studies of new cytisine derivatives, as ligands for neuronal nicotinic acetylcholine receptor subtypes", Journal of Medicinal Chemistry. vol. 52, pp. 4345-4357, 2009.

62. I. Murakoshi, K. Fukuchi, J. Haginiwa, S. Ohmiya, H. Otomasu, "N-(3oxobutyl)cytisine: a new lupin alkaloid from Echinosophora koreensis", Phytochemistry, vol. 16, pp. 1460, 1977. 
63. S.K. Chellappan, Y. Xiao, W. Tueckmantel, K.J. Kellar, A.P. Kozikowski, "Synthesis and pharmacological evaluation of novel 9- and 10-substituted cytisine derivatives. Nicotinic ligands of enhanced subtype selectivity", Journal of Medicinal Chemistry, vol. 49, pp. 2673-2676, 2006.

64. E. Schmidt, J. Lammers, "Beiträge zur Kenntnis des Cytisins", Archives of Pharmacy, vol. 235, pp. 374-394, 1897.

65. A. Orjales, I. Ribas, A. Varela, Annuals of Quimistry, vol. 68, pp. 1419-1422, 1972.

66. N. Houllier, J. Gopisetti, P. Lestage, M.-C. Lasne, J. Rouden, "Identification of 9-fluoro substituted (-)-cytisine derivatives as ligands with high affinity for nicotinic receptors", Bioorganic and Medicinal Chemistry Letters, vol. 20, pp. 6667-6670, 2010.

67. R.W. Fitch, Y. Kaneko, P. Klaperski, J.W. Daly, G. Seitz, D. Gündisch, "Halogenated and isosteric cytisine derivatives with increased affinity and functional activity at nicotinic acetylcholine receptors", Bioorganic and Medicinal Chemistry Letters, vol. 15, pp. 1221-1224, 2005.

68. Y.S. Mineur, C. Eibl, G. Young, C. Kochevar, R.L. Papke, D. Gundisch, M.R. Picciotto, "Cytisine-based nicotinic partial agonists as novel antidepressant compounds", Journal of Pharmacological and Experimentals Therapies, vol. 329, pp. 377-386, 2009.

69. Y.S. Mineur, E.B. Einstein, P.A. Seymour, J.W. Coe, B.T. O’Neill, H. Rollema, M.R. Picciotto, " $\alpha 4 \beta 2$ nicotinic acetylcholine receptor partial agonists with low intrinsic efficacy have antidepressantlike properties", Behavioural Pharmacology, vol. 22, pp. 291-299, 2011.

70. B.K. Cassels, I. Bermudez, F. Dajas, J.A. Abin-Carriquiry, S. Wonnacottd, "From ligand design to therapeutic efficacy: the challenge for nicotinic receptor research", Drug Discovery Today vol. 10, pp.1657-1665, 2005.

71. P.A. Crooks, M.T. Bardo, L.P. Dwoskin, Nicotinic receptor antagonists as treatments for nicotine abuse, Advances in Pharmacology vol. 69, pp. 513-551, 2014.

72. K. Cahill K, N. Lindson-Hawley, K.H. Thomas, T.R. Fanshawe, T. Lancaster, "Nicotine receptor partial agonists for smoking cessation“, Database Systematic Review, DOI: 10.1002/14651858.CD006103.pub7, 2016.

73. F.R. Struth, C. Hirschhäuser, "A Modular Approach to the Asymmetric Synthesis of Cytisine", European Journal of Organic Chemistry, DOI: 10.1002/ejoc.201501435, 2016.

74. D. Bartusik, D. Aebisher, P. Tutka, "In vivo imaging studies of cytisine", Biointerface Research in Applied Chemistry, vol. 6, pp. 1288-1290, 2016. 